\title{
Analysis of the Mainstreaming Program for Religious Moderation for Students: Study of Ministerial Regulation of Education and Culture Number 45 of 2014
}

\author{
Dudiyono $^{1 *}$, Slamet Wahyudi ${ }^{2}$, Kholid Mawardi ${ }^{3}$ \\ ${ }^{12}$ Doctoral Program at UIN Prof. K.H. Saifuddin Zubri, Purwokerto, ${ }^{3}$ UIN Prof. \\ K.H. Saifuddin Zubri, Purwokerto
}

Corresponding Author: ${ }^{1201771003 @ m b s . i a i n p u r w o k e r t o . a c . i d ~}$

Article History:

Submit:

2021-07-17

Publish:

2022-02-28
Abstract

Indonesia as an archipelagic country, has ethnic, linguistic, religious, cultural and social statuses. Religious moderation is an essential aspect in managing religious life in a plural and multicultural Indonesian society. In education discourse, religious moderation is an interesting issue, where currently, people in Indonesia have given serious attention to religious moderation. The purpose of this study is to find out what aspects of the Religious Moderation Mainstreaming program for students by examining Permendikbud No. 45 of 2014 concerning school uniforms for students at primary and secondary education levels. The research method is qualitative with a literature study approach. The conclusions in this study are 1) The mainstreaming program of religious moderation in schools. Where educational institutions can play a strategic role in religious moderation. 2) School uniforms as religious moderation, 3) School uniforms and religious rights, Identity in the form of this uniform initiates people's views of the religion adopted by students, and 4) School uniforms and attitudes of nationalism in religious moderation as a culture of tolerance which is described through respecting others, nationalism is related to the student's commitment to prioritizing the national interest. Keyword: Religious Moderation; Uniforms; Identity; Nationalism 
Journal Homepage http://ijssr.net/index.php/ijssr

This is an Open Access article under the CC BY SA license

https://creativecommons.org/licenses/by-sa/4.0/

Published by

Indonesian Academy of Social and Religious Research

\section{Introduction}

Indonesia is an archipelagic country with ethnic, linguistic, religious, cultural and social statuses. This diversity is a natural event because of the meeting of various cultures, the interaction of various individuals and groups bringing cultural behaviour, having different and specific ways of life. Diversities such as cultural diversity, family background, religion, and ethnicity interact in an Indonesian community. ${ }^{1}$

Currently, Indonesia is stirred up by the news of the coercion of SMK Negeri 2 Padang students to wear hijab, reported by kompas.com that at SMK Negeri 2 Padang, there is a mandatory hijab rule for all students, including non-Muslim students. Information about the mandatory hijab rule was widely discussed and received public attention after a video circulated of arguments between the school and non-Muslim parents who questioned the rules regarding the mandatory hijab for all students. ${ }^{2}$ According to Ministerial Regulation of Education and Culture No. 45 of 2014, school uniforms do not require specific religious-specific clothing models as student uniforms. In addition, schools may not make regulations or appeals for students to use specific religious clothing models as school uniforms. Even though Indonesia is a pluralistic country that has a diversity of tribes, cultures, religions, and customs.

Diversity is a necessity in this life. Diversity as sunnatullab that can be seen in this nature. Allah created this world on the sunnah of diversity within a framework of unity. Within a framework of human unity, we see how God created various ethnic groups. Within the unity of a nation, Allah created various ethnic groups, tribes, and groups. Within the framework of the unity of a language, Allah created various dialects of each. Within the framework of the unity of the Sharisah, Allah created various schools of thought as a result of their respective ijtihad. Within the framework of the unity of the people

1 Agus Akhmadi, "Moderasi Beragama dalam Keragaman Indonesia," Jurnal Diklat Keagamaan 3, no. 2 (2019): 45-55, https://doi.org/https://bdksurabaya.e-journal.id/bdksurabaya/article/view/82.

2 Retia Kartika Dewi, "Sesalkan Aturan Wajib Berjilbab Siswi Non-Muslim, Kemendikbud Minta Sekolah Taat Permendikbud," kompas.Com, 2021, https://www.kompas.com/tren/ $\mathrm{read} / 2021 / 01 / 24 / 121500265 /$ sesalkan-aturan-wajib-berjilbab-siswi-non-muslim-kemendikbudminta-sekolah?page=all. 
(ummatan wabidab), Allah created various religions. This diversity in religion is a sunnatullah, so its existence cannot be denied. ${ }^{3}$

Framing religious moderation is essential in managing religious life in a plural and multicultural Indonesian society. Interestingly, it turns out that all recognized religions in Indonesia also recognize the teachings of religious moderation. In Islam, for example, there is the concept of washatiyah, which has an equivalent meaning with the words tawassuth (middle), i'tidal (fair), and tawazun (balanced). In Christianity, religious moderation is a perspective to mediate the extremities of interpretation of Christian teachings understood by some people. Moderation of religion in the perspective of the Catholic Church with the term «open〉 to sundamentalists and straditionalists (which rejects reform in the sense of the Catholic Church). In Hinduism, religious moderation is known in ethics, where this still means maintaining a harmonious relationship between humans with one another, which is one of the three causes of prosperity. In Buddhism, it can be seen from Siddhartha Gautama. He made four vows, which consisted of trying to help all sentient beings, rejecting worldly desires, studying, living, practising the Dharma, and striving for complete enlightenment. In Confucianism, Confucians who are junzi (faithful and virtuous) view life in the perspective of yin yang, because yin yang is the philosophy, thought, and spirituality of Confucians who want to live in the dao Yin yang is the moderate stance, not the extreme stance. Anything less is as wrong as something in excess. ${ }^{4}$

The importance of the middle path in religion as written by Fathorrahman Ghufron, Mainstreaming Moderate Islam, actually has its urgency value continuously echoed by religious leaders, campus academics, and teachers in schools with authority and through various media channels. Such promotion of the middle path is specifically to provide education to students that being extreme in religion, on any side, will always lead to clashes/conflicts..$^{5}$ Especially in the era of globalization in recent years, we are more likely to deal with individuals and groups of different religions, where we live side by side with other people of different religions, this can then cause fundamental problems in our society today. ${ }^{6}$

3 Mohammad Fahri and Ahmad Zainuri, "Moderasi Beragama Di Indonesia," Intizar 25, no. 2 (2019): 95-100, https://doi.org/10.19109/intizar.v25i2.5640.

4 Edy Sutrisno, "Aktualisasi Moderasi Beragamadi Lembaga Pendidikan," Jurnal Bimas Islam 12, no. 2 (2019): 323-48, https://doi.org/10.37302/jbi.v12i2.113.

5 Sutrisno.

6 Joshua N. Hook et al., "Intellectual Humility and Religious Tolerance," The Journal of Positive Psychology 12, no. 1 (2016): 29-35, https://doi.org/10.1080/17439760.2016.1167937. 
Religious moderation is important because currently, there are real challenges faced by the world's major religions, which consist of extremism, radicalism, intolerance, and exclusivism. These ideologies often use violence to demonstrate their existence and infect the community and become an epidemic among students, lecturers, scientists, and activists of mass organizations and religious organizations. In Indonesia, for example, this ideology entered university campuses, which caused many students and lecturers to become extreme, radical, intolerant, and exclusive. ${ }^{7}$ Therefore, religious moderation and educational discourse are exciting issues, where currently people in Indonesia have given serious attention to religious moderation, especially after many violent incidents occurred at the local, national, regional and global levels in the name of religion. ${ }^{8}$ And education is the way to overcome that, ${ }^{910}$ Education is a means to advance the nation and national culture by developing aspects of the human personality consisting of knowledge, attitudes and skills. As an effort to prepare quality human resources, education in Indonesia is carried out based on the Law of the Republic of Indonesia No. 20 of 2003 concerning the National Education System, which states that "to develop the potential of students to become human beings who believe and fear God Almighty. One, noble character, healthy, knowledgeable, capable, creative, independent and become a democratic and responsible citizen. The purpose of education contains a description of the values that are good, noble, appropriate, and beautiful for life. ${ }^{11}$

Several researchers have carried out this research on religious moderation: First, this research was conducted by Moh. Badrul Munir and Herianto whose results are the level of understanding of religious moderation and its correlation to

7 Fadlil Munawwar Manshur and Husni, "Promoting Religious Moderation through Literary-Based Learning: A Quasi-Experimental Study," International Journal of Advanced Science and Technology 29, no. 6 (2020): 5849-55, http://sersc.org/journals/index.php/IJAST/article/view/19864.

8 Erwin Mahrus, Zaenuddin Hudi Prasojo, and Busro, "Messages of Religious Moderation in Sambas Islamic Manuscripts," MADANLA 24, no. 1 (2020): 39-48, https://doi.org/10.29300/madania. v24i1.3283.

9 Hugh McLeod, "Christianity and Nationalism in Nineteenth-Century Europe," International Journal for the Study of the Christian Church 15, no. 1 (2015): 7-22, https://doi.org/10.1080/147422 5X.2015.1020009.

10 Rhys Jones, Peter Merriman, and Sarah Mills, "Youth Organizations and the Reproduction of Nationalism in Britain: The Role of Urdd Gobaith Cymru," Social \& Cultural Geography 17, no. 5 (2016): 714-34, https://doi.org/10.1080/14649365.2016.1139166.

11 Ali Susanto and Muh. Farozin, "PENGARUH KONFORMITAS, KETERAMPILAN SOSIAL DAN PERSEPSI TERHADAP SINETRON ANAK JALANAN TERHADAP PERILAKU AGRESIF," Harmoni Sosial: Jurnal Pendidikan IPS 5, no. 1 (2018): 93-104, https://journal.uny.ac.id/ index.php/hsjpi/article/view/15001/11415. 
the influence of mental health, organizational activity and academic achievement, the results of which are mental health, organizational activity and academic achievement that can affect the level of understanding of students' religious moderation. ${ }^{12}$ Second, research by Nirwana Jumala with the title Moderation of Thinking to Occupy the Highest Spiritual Levels in Religion, the result is that a moderate person will find peace in his life. The most beautiful peace is when we are at the highest spiritual level of religion. These levels range from the selfish to the sacred according to God's commandments. The levels consist of nafsu al-amārah, nafsu al-lawwāmah, nafsu al-mulbimma, nafsu al-muța'innah, nafsu ar-radiyah, nafsu al-mardiah dan nafsu as-safiyah. Moderation in thinking is needed to climb each of these levels because moderation in thinking will lead to moderation in religion. ${ }^{13}$ Third, Yedi Purwanto et al. with the title Internalization of Moderation Values through Islamic Religious Education in Public Universities, resulted in internalizing the moderate values of PAI UPI, carried out: a). through PAI courses in class, b). through strengthening Tutorial integration activities, c) by guiding student activity units, and d). through other activities that support the achievement of moderation values for students, such as launching the dangers of radicalism movement at UPI, holding seminars on the dangers of radicalism, and other activities. ${ }^{14}$ Fourth, the research conducted by Fadlil Munawwar Mansur and Husni with the title Promoting Religious Moderation through Literary-based Learning: A Quasi-Experimental Study, the result of which is that literature-based learning is beneficial in encouraging and developing moderate religious attitudes. Literature-based learning has succeeded in increasing students' understanding of the importance of religious moderation and developing moderate attitudes and behaviour in religion, and creating sincere ethics and friendship for followers of different religions. ${ }^{15}$ Fifth, research by Irwan Faturrochman et al. with the title Revitalization of Islamic Boarding

12 Moh. Badrul Munir and Herianto, "Tingkat Pemahaman Moderasi Beragama Serta Korelasinya Terhadap...I137Tingkat Pemahaman Moderasi Beragama Serta Korelasinya Terhadap Pengaruh Kesehatan Mental, Keaktifan Berorganisasi Dan Prestasi Akademik," in Prosiding Nasional: Peluang Dan Tantangan Studi Islam Interdisipliner Dalam Bingkai Moderasi, 2020, 137-50, http://prosiding. iainkediri.ac.id/index.php/pascasarjana/article/view/46.

13 Nirwani Jumala, "Moderasi Berpikir Untuk Menempati Tingkatan Spiritual Tertinggi Dalam Beragama," Substantia 21, no. 2 (2019): 170-84, https://doi.org/10.22373/substantia.v21i2.5526.

14 Yedi Purwanto et al., "Internalisasi Nilai Moderasi Melalui Pendidikan Agama Islam Di Perguruan Tinggi Umum," EDUKASI: Jurnal Penelitian Pendidikan Agama Dan Keagamaan 17, no. 2 (2019): 110-24, https://doi.org/10.32729/edukasi.v17i2.605.

15 Manshur and Husni, "Promoting Religious Moderation through Literary-Based Learning: A QuasiExperimental Study.” 
School Management to Foster the Spirit of Islamic Moderation in Indonesia which resulted in the significant role of Islamic boarding school administrators in preventing radicalism by creating commitment and not providing the slightest opportunity for the emergence of radicalism in Indonesia. Islamic boarding school environment, restore the position of the existence of Islamic boarding schools as tafaqquh fiddin and boarding school administrators are committed not to get involved in practical politics, strictly monitor all programs in Islamic boarding schools so that they are free from radicalism and the spirit of Islamic moderation is used as a foothold in the practice of religious life so that pesantren become a driving force in fostering the spirit of Islamic moderation. ${ }^{16}$

In this study, researchers will examine religious moderation in students/ students in schools in the study of Permendikbud No. 45 of 2014 concerning school uniforms for students at primary and secondary education levels. ${ }^{17}$ The purpose of the research is to find out what aspects of the mainstreaming program of religious moderation in students according to Ministerial Regulation of Education and Culture No. 45 of 2014 concerning school uniforms for students at primary and secondary education levels.

\section{Religious Moderation}

The word moderation comes from the Latin moderatio, which means moderate (not too much and not too little). According to the Big Indonesian Dictionary (KBBI), moderation has two meanings: (1) reducing violence; (2) avoid extremes. In English, the word moderation has the meaning of core, standard, or nonaligned. While in Arabic, moderation is called wasath or wasathiyah which has the same meaning as tawassuth (middle). Moderation (al-wasathiyah) balances two directions or opposite two directions or two directions, where one of the two parties cannot take more rights to the other party and overlaps with each other.

Moderation, according to Qardawi, is divided into several areas, namely: First, ideology. Ideologically, Islam is not a religion that glorifies humans but also does not consider humans as slaves. Second, ritual worship. Islam is a

16 Irwan Faturrochman, Dina Hajja Ristiant, and Mohamad Aziz Shah bin Mohamed Arif,"Revitalization of Islamic Boarding School Management to Foster the Spirit of Islamic Moderation in Indonesia," Jurnal Pendidikan Islam 8, no. 239-258 (2019), https://doi.org/10.14421/jpi.2019.82.239-258.

17 MENTERI PENDIDIKAN DAN KEBUDAYAAN REPUBLIK INDONESIA, "PERATURAN MENTERI PENDIDIKAN DAN KEBUDAYAAN REPUBLIK INDONESIA NOMOR 45 TAHUN 2014 TENTANG PAKAIAN SERAGAM SEKOLAH BAGI PESERTA DIDIK JENJANG PENDIDIKAN DASAR DAN MENENGAH," 2014. 
religion that prioritizes worship but still encourages social attitudes in society. So Islam does emphasize not only the rubûbiyah aspect but also the human aspect. Third, morality (morals). In this case, humans are seen as creatures who have animal instincts and spirituality. Moreover, a person's behaviour in religion can be classified as moderate or otherwise extreme, where religious behaviour has benchmarks, indicators, and limits. This benchmark in religion is made based on reliable sources, such as the state constitution, local wisdom, consensus or mutual agreement. $^{18}$

\section{Research Method}

The research used in this study was qualitative. The method used in this research is a literature study. A literature study is a series of research activities related to library data collection methods such as books, journals, reading, recording, and processing research materials. In literature study research, there are four main characteristics that the authors need to pay attention to, including First, researchers deal directly with the text. Second, researchers do not go directly to the field because researchers deal directly with data sources in the library. Third, the library data used are generally secondary sources, meaning that researchers obtain research data from second-hand sources and not original/original data from the first data in the field. Fourth, that the condition of library data is not limited by space and time. ${ }^{19}$

Based on the previous, the data collection in this study was carried out by reviewing and exploring several journals, books, and documents and data sources following religious moderation and Ministerial Regulation of Education and Culture No. 45 of 2014 concerning school uniforms primary and secondary education levels.

\section{Result and Discussion}

1. Religious moderation mainstreaming program in schools

The Ministry of Religion continues to prioritize plans related to mainstreaming religious moderation. In the opening of the National Dialogue on Religion and Ethnicity held in Makassar, South Sulawesi by the Minister

18 Mahrus, Prasojo, and Busro, "Messages of Religious Moderation in Sambas Islamic Manuscripts."

19 Supriyadi, "Community Of Practitioners : Solusi Alternatif Berbagi Pengetahuan Antar Pustakawan," Lentera Pustaka Jurnal Ilmu Perpustakaan Informasi Dan Kearsipan 2, no. 2 (2017): 83-93, https://doi. org/10.14710/lenpust.v2i2.13476. 
of Religion Lukman Hakim Saifuddin. Minister of Religion Lukman Hakim Saifuddin said that religion and the state need each other. The relationship between the two is symbiotic. Religion needs a state platform, and national life requires religious values as a guideline that becomes a reference in various national and state lives. The Minister of Religion said: "Because all state administrators must be controlled and balanced with religious values so that governance is not dull and in essence, the maintenance of religious restrictions will protect Indonesia". ${ }^{20}$

In its implementation in schools, educational institutions can play a strategic role in religious moderation. Peace education can be combined with school curricula, constructive conflict resolution, peer mediation, and negotiation to provide an educational method for all students, resulting from joint efforts in Indonesia. Extensive and non-partial knowledge of religion must be taught in educational institutions to have a strong foundation of religious understanding. ${ }^{21}$

2. School uniforms as religious moderation

Based on article 2 letter an of the Ministerial Regulation of Education and Culture of the Republic of Indonesia Number 45 of 2014 which reads that school uniforms aim to instil and foster a sense of nationalism, togetherness, and strengthen brotherhood to foster a spirit of unity and unity among students. Based on Kristina Bakkær Simonsen and Bart Bonikowski who state that patriotism, which is defined as a positive influence on a nation combined with a robust national identification. ${ }^{22}$ Furthermore, the need to complement the basis of nationalism with everyday life to capture better the process of national reproduction in increasing ethnic-cultural diversity in a nation. ${ }^{23}$ One of them is through education. ${ }^{24}$

${ }^{20}$ Data dan Informasi Kemenag bersama Tim Komunikasi Pemerintah Kemkominfo Biro Humas, “Kemenag Terus Prioritaskan Program Pengarusutamaan Moderasi Beragama," 2019, https://kominfo. go.id/index.php/content/detail/18041/kemenag-terus-prioritaskan-program-pengarusutamaanmoderasi-beragama/0/artikel_gpr.

21 Samsul AR, "Peran Guru Agama Dalam Menanamkan Moderasi Beragama," Al-Irfan 3, no. 1 (2020): 37-51, https://doi.org/10.36835/al-irfan.v3i1.3715.

22 KRISTINA BAKKÆR SIMONSEN and BART BONIKOWSKI, "Is Civic Nationalism Necessarily Inclusive? Conceptions of Nationhood and Anti-Muslim Attitudes in Europe," European Journal of Political Research 59 (2019): 114-36, https://doi.org/10.1111/1475-6765.12337.

${ }_{23}$ Marco Antonsich, "The 'Everyday' of Banal Nationalism - Ordinary People's Views on Italy and Italian," Political Geography 54 (2016): 32-42, https://doi.org/10.1016/j.polgeo.2015.07.006.

24 Anssi Paasi, "Dancing on the Graves: Independence, Hot/Banal Nationalism and the Mobilization of Memory,” Political Geography 54 (2016): 21-31, https://doi.org/10.1016/j.polgeo.2015.07.005. 
3. School uniforms and religious rights

Article 3 paragraph 4 letter d states that school uniforms are regulated by each school while still considering the rights of every citizen to practice their respective religious beliefs. The article is based on Article 29 of the 1945 Constitution, which states that the State is based on the One Godhead, and the State guarantees the independence of each resident to embrace their respective religions and worship according to their religion and beliefs. The provisions of Article 29 of the 1945 Constitution, which states that the State is based on God Almighty, implies that the State is obliged to make laws and regulations or carry out policies to implement a sense of faith in God Almighty. In addition, the State should make laws and regulations that prohibit anyone from harassing religious teachings. This religious right is one of the rights that every citizen has the right to regulate themselves. ${ }^{25}$

In connection with the law, Nadiem Makarim, as Minister of Education and Culture of the Republic of Indonesia, reported from kompas.com that schools should not regulate students to use specific religious clothing models as uniforms schools. Permendikbud concerning school uniforms does not require certain religious specific clothing models as school uniforms. ${ }^{26}$ This uniform identity initiates people to see themselves as integrated into the social environment. Through their identification with or separation from a particular group, Shiva grows a sense of themselves and thus gives meaning and purpose to their lives. Because the process of forming this identity shapes the behaviour and actions of students at school. ${ }^{27}$

4. School uniforms and attitudes of nationalism

According to Roy, nationalism is an ideology that worships the nation, ${ }^{28}$ and the uniform is a symbol of the nation. ${ }^{29}$ Nationalism in religious moderation is a

${ }_{25}$ McLeod, "Christianity and Nationalism in Nineteenth-Century Europe."

${ }^{26}$ Irfan Kamil, "Nadiem: Sekolah Tak Boleh Wajibkan Siswa Berseragam Model Pakaian Agama Tertentu,” 2021, https://nasional.kompas.com/read/2021/01/24/18063551/nadiem-sekolah-takboleh-wajibkan-siswa-berseragam-model-pakaian-agama?page=all.

27 Mark Tomass, The Significance of Religious Identity, The Religious Roots of the Syrian Conflict (New York: Palgrave Macmillan, 2016), https://doi.org/10.1057/9781137525710_2.

${ }^{28}$ Christian Fuchs, "M. N. Roy and the Frankfurt School: Socialist Humanism and the Critical Analysis of Communication, Culture, Technology, Fascism and Nationalism," TripleC 17, no. 2 (2019): 249-86, https://doi.org/10.31269/triplec.v17i2.1118.

29 Jennifer Midberry, "Photos of Breastfeeding in Uniform: Contesting Discourses of Masculinity, Nationalism, and the Military," Feminist Media Studies 17, no. 6 (2017): 972-87, https://doi.org/10.1 080/14680777.2017.1283340. 
culture of tolerance that is described by respecting others. Nationalism is related to students' commitment to prioritizing national interests. ${ }^{30}$

Nationalism as an ideology can be seen from physical appearance actively is a crucial strategy in which the state instils an ideology in students and becomes the primary way for students in Indonesia to experience and understand the nation. For most Indonesians, the only time in their life when they play a formal role in an official national show is as a student at school. As the most visible and frequent display of national identity in many communities, school performance is a crucial dimension of national identity embodied daily. This identity is one of the school uniforms used, wherefrom the uniform will appear the identity of nationalism in students. ${ }^{31}$

Nationalism is often seen as an integral part of Christianity. The readiness to die for the motherland was presented as a Christian obligation, and, in particular, Christian preachers in this era were greatly influenced by the concept of a Godgiven national mission. ${ }^{32}$ In other religions, it is the same as in Islam, and it is called hubbul wathon.

\section{Discussion}

In schools to strengthen religious moderation, based on research by Samsul AR, religious moderation in educational institutions is very important because teachers have an essential role in providing a broad understanding and understanding of religions that can respect differences. Religious moderation is part of a joint effort so that the Indonesian nation avoids division because the division is the beginning of the destruction of a nation. The implementation of religious moderation in the teaching and learning process can be done using discussion, group work, and field trips. With these three methods, teachers can easily understand diversity, respect others, respect other people's opinions, and be tolerant. In addition to educating and providing understanding to students how important it is to live, love and respect the right to life, worship according to their respective beliefs. ${ }^{33}$

30 Arita Marini, "Integration of Character Values in School Culture at Elementary Schools in Jakarta, Indonesia," Journal of Arts \& Humanities 6, no. 5 (2017): 21-32, https://doi.org/10.18533/journal. v6i5.1171.

31 Sarah Moser, "Educating the Nation: Shaping Student-Citizens in Indonesian Schools," Children's Geographies 14, no. 3 (2015): 247-62, https://doi.org/10.1080/14733285.2015.1033614.

32 McLeod, "Christianity and Nationalism in Nineteenth-Century Europe."

33 AR, "Peran Guru Agama Dalam Menanamkan Moderasi Beragama." 
Nationalism that develops because of the similarity of fate and history, as well as the interests of living together as an independent, united, sovereign, democratic, and advanced nation in the unity of the nation and state. In addition, several common goals can be achieved, maintaining and giving the identity, unity, prosperity, strength, or strength of the country concerned-the concept of nationalism or nationality. According to Kohn, it is a shared will Living as a nation or believing that the highest allegiance of individuals must obey the nation-state. ${ }^{34}$

Loving for the homeland and national spirit (nationalism) is one of the 18 cultural values and national character implemented by schools. There are three ways to realize the development of these values in schools, namely: 1) integrating values through discipline; 2) integrating values through self-development activities (extracurricular and counselling); 3) integrating values through school cultural activities. ${ }^{35}$ This culture is one of the uniforms used in schools because culture results from the mind and human power depicted in schools' uniforms.

Uniforms are a brand of identity, a marker of identity, and a silent but visual form of social relations. It can communicate multi-layered messages that embody different meanings for the viewer where each other has different perceptions at the same time. And uniforms are part of the brand identity where uniforms have been used to highlight and convey consistency within a group and differentiate who is who in a workspace or school. ${ }^{36}$ Therefore, religious identity in schools must be neutral, where schools may not highlight one religion in the uniforms worn by students as a form of religious moderation in schools.

The official national identity is preserved and normalized through repeated performances of nationalism. In Europe, school teachers instil in their students a strong sense of national identity. ${ }^{37}$ Many previous studies have looked at the relationship between power, nation-building and education, where the literature has focused on curriculum and bureaucratic structures rather than on the experiences embodied by students and the way national identities are engraved

34 Yustiani, "NASIONALISME MELALUI PENDIDIKAN DI SEKOLAH PADA SISWA SMA DI WILAYAH PERBATASAN KALIMANTAN BARAT,” Jurnal SMaRT Studi Masyarakat, Religi Dan Tradisi 4, no. 1 (2018): 111-23, https://doi.org/10.18784/smart.v4i1.578.g324.

35 Sulistyowati Endah, Implementasi Kurikulum Pendidikan Karakter (Yogyakarta: Citra Aji Parama, 2012).

36 Nanik Rianandita Sarir, "Morning Sen': Interaction, Habitus and the Importance of Uniform as Identity in Aviation College," Komunitas: International Journal of Indonesian Society and Culture 9, no. 2 (2017): 292-301, https://doi.org/10.15294/komunitas.v9i2.10569.

37 McLeod, "Christianity and Nationalism in Nineteenth-Century Europe." 
on the student body in schools. The conceptualization of continuous reinvention of the nation through the student body in Indonesian schools as performative is a way to approach nation-building through education at the best possible political space scale. Furthermore, teachers can negotiate the geopolitical aspect of the curriculum, which is the centre of national identity in diversity, to form religious moderation in students. ${ }^{38}$

Education policy and investigate how public schools in Indonesia are essential in which national identity is instilled in students with varying degrees of success through students' performance. How the student body through the school uniforms it wears later becomes an important site for nation-building and how performativity can help conceptualize repetition and citation practices critical in preserving religious moderation.

This religious moderation through education serves as a critical ideological instrument for the state to legitimize and naturalize its power. One of the critical functions of mass education is to bring a diverse population into direct contact with the state's ideological apparatus to mingle later and moderate who then conceptualize education as a 'means for resolving the tension of differentiation' and as a 'universalistic integration structure. ${ }^{39}$

\section{Conclusion}

This study states that students' religious moderation follows Ministerial Regulation of Education and Culture No. 45 of 2014 concerning school uniforms for students at primary and secondary education levels. It can be seen from several aspects: 1) Mainstreaming religious moderation programs in schools. Educational institutions can play a strategic role in religious moderation. 2) School uniforms as religious moderation, 3) School uniforms and religious rights, Identity in the form of this uniform initiates people's views of the religion adopted by students, and 4) School uniforms and attitudes of nationalism in religious moderation as a culture of tolerance which is described through respecting others, nationalism is related to the student's commitment to prioritizing the national interest.

The limitation of this research lies in its discussion, which only focuses on Ministerial Regulation of Education and Culture No. 45 of 2014 concerning school uniforms for students at primary and secondary education levels. This was

\footnotetext{
38 Jones, Merriman, and Mills, "Youth Organizations and the Reproduction of Nationalism in Britain: The Role of Urdd Gobaith Cymru."

39 Moser, "Educating the Nation: Shaping Student-Citizens in Indonesian Schools."
} 
chosen because these aspects have relevance in applying religious moderation for students through the school uniform they wear.

\section{References}

Akhmadi, Agus. "Moderasi Beragama dalam Keragaman Indonesia." Jurnal Diklat Keagamaan 3, no. 2 (2019): 45-55. https://doi.org/https://bdksurabaya.e-journal. $\mathrm{id} / \mathrm{bdksurabaya/article/view/82.}$

Antonsich, Marco. "The 'Everyday' of Banal Nationalism - Ordinary People's Views on Italy and Italian.” Political Geography 54 (2016): 32-42. https://doi. org/10.1016/j.polgeo.2015.07.006.

AR, Samsul. "Peran Guru Agama Dalam Menanamkan Moderasi Beragama." AlIrfan 3, no. 1 (2020): 37-51. https://doi.org/10.36835/al-irfan.v3i1.3715.

Biro Humas, Data dan Informasi Kemenag bersama Tim Komunikasi Pemerintah Kemkominfo. "Kemenag Terus Prioritaskan Program Pengarusutamaan Moderasi Beragama,” 2019. https://kominfo.go.id/index.php/content/ detail/18041/kemenag-terus-prioritaskan-program-pengarusutamaanmoderasi-beragama/0/artikel_gpr.

Dewi, Retia Kartika. "Sesalkan Aturan Wajib Berjilbab Siswi Non-Muslim, Kemendikbud Minta Sekolah Taat Permendikbud.” Kompas.Com, 2021. https:// www.kompas.com/tren/read/2021/01/24/121500265/sesalkan-aturan-wajibberjilbab-siswi-non-muslim-kemendikbud-minta-sekolah?page=all.

Endah, Sulistyowati. Implementasi Kurikulum Pendidikan Karakter. Yogyakarta: Citra Aji Parama, 2012.

Fahri, Mohammad, and Ahmad Zainuri. "Moderasi Beragama Di Indonesia." Intizar 25, no. 2 (2019): 95-100. https://doi.org/10.19109/intizar.v25i2.5640.

Faturrochman, Irwan, Dina Hajja Ristiant, and Mohamad Aziz Shah bin Mohamed Arif. "Revitalization of Islamic Boarding School Management to Foster the Spirit of Islamic Moderation in Indonesia." Jurnal Pendidikan Islam 8, no. 239 258 (2019). https://doi.org/10.14421/jpi.2019.82.239-258.

Fuchs, Christian. "M. N. Roy and the Frankfurt School: Socialist Humanism and the Critical Analysis of Communication, Culture, Technology, Fascism and Nationalism." TripleC 17, no. 2 (2019): 249-86. https://doi.org/10.31269/ triplec.v17i2.1118. 
Hook, Joshua N.,Jennifer E. Farrell, Kathryn A. Johnson, Daryl R. Van, Tongeren, Don E. Davis, and Jamie D. Aten. "Intellectual Humility and Religious Tolerance." The Journal of Positive Psychology 12, no. 1 (2016): 29-35. https://doi.org/10.108 0/17439760.2016.1167937.

Indonesia, Menteri Pendidikan dan Kebudayaan Republik. "Peraturan Menteri Pendidikan dan Kebudayaan Republik Indonesia Nomor 45 Tahun 2014 Tentang Pakaian Seragam Sekolah bagi Peserta Didik Jenjang Pendidikan Dasar dan Menengah," 2014.

Jones, Rhys, Peter Merriman, and Sarah Mills. "Youth Organizations and the Reproduction of Nationalism in Britain: The Role of Urdd Gobaith Cymru." Social \& Cultural Geography 17, no. 5 (2016): 714-34. https://doi.org/10.1080/1 4649365.2016.1139166.

Jumala, Nirwani. "Moderasi Berpikir Untuk Menempati Tingkatan Spiritual Tertinggi Dalam Beragama.” Substantia 21, no. 2 (2019): 170-84. https://doi. org/10.22373/substantia.v21i2.5526.

Kamil, Irfan. "Nadiem: Sekolah Tak Boleh Wajibkan Siswa Berseragam Model Pakaian Agama Tertentu,” 2021. https://nasional.kompas.com/ $\mathrm{read} / 2021 / 01 / 24 / 18063551 /$ nadiem-sekolah-tak-boleh-wajibkan-siswaberseragam-model-pakaian-agama?page=all.

Mahrus, Erwin, Zaenuddin Hudi Prasojo, and Busro. "Messages of Religious Moderation in Sambas Islamic Manuscripts." MADANLA 24, no. 1 (2020): 3948. https://doi.org/10.29300/madania.v24i1.3283.

Manshur, Fadlil Munawwar, and Husni. "Promoting Religious Moderation through Literary-Based Learning: A Quasi-Experimental Study." International Journal of Advanced Science and Technology 29, no. 6 (2020): 5849-55. http://sersc.org/ journals/index.php/IJAST/article/view/19864.

Marini, Arita. "Integration of Character Values in School Culture at Elementary Schools in Jakarta, Indonesia." Journal of Arts \& Humanities 6, no. 5 (2017): 2132. https://doi.org/10.18533/journal.v6i5.1171.

McLeod, Hugh. "Christianity and Nationalism in Nineteenth-Century Europe." International Journal for the Study of the Christian Church 15, no. 1 (2015): 7-22. https://doi.org/10.1080/1474225X.2015.1020009.

Midberry, Jennifer. "Photos of Breastfeeding in Uniform: Contesting Discourses of Masculinity, Nationalism, and the Military." Feminist Media Studies 17, no. 6 (2017): 972-87. https://doi.org/10.1080/14680777.2017.1283340. 
Moser, Sarah. "Educating the Nation: Shaping Student-Citizens in Indonesian Schools." Children's Geographies 14, no. 3 (2015): 247-62. https://doi.org/10.108 0/14733285.2015.1033614.

Munir, Moh. Badrul, and Herianto. "Tingkat Pemahaman Moderasi Beragama Serta Korelasinya Terhadap...I137Tingkat Pemahaman Moderasi Beragama Serta Korelasinya Terhadap Pengaruh Kesehatan Mental, Keaktifan Berorganisasi Dan Prestasi Akademik." In Prosiding Nasional: Peluang Dan Tantangan Studi Islam Interdisipliner Dalam Bingkai Moderasi, 137-50, 2020. http://prosiding. iainkediri.ac.id/index.php/pascasarjana/article/view/46.

Paasi, Anssi. "Dancing on the Graves: Independence, Hot/Banal Nationalism and the Mobilization of Memory." Political Geography 54 (2016): 21-31. https://doi. org/10.1016/j.polgeo.2015.07.005.

Purwanto, Yedi, Qowaid, Lisa'diyah Ma'rifataini, and Ridwan Fauzi. "Internalisasi Nilai Moderasi Melalui Pendidikan Agama Islam Di Perguruan Tinggi Umum.” EDUKASI:Jurnal Penelitian Pendidikan Agama Dan Keagamaan 17, no. 2 (2019): 110-24. https://doi.org/10.32729/edukasi.v17i2.605.

Sarir, Nanik Rianandita. "Morning Sen': Interaction, Habitus and the Importance of Uniform as Identity in Aviation College." Komunitas: International Journal of Indonesian Society and Culture 9, no. 2 (2017): 292-301. https://doi.org/10.15294/ komunitas.v9i2.10569.

SIMONSEN, KRISTINA BAKKÆR, and BART BONIKOWSKI. "Is Civic Nationalism Necessarily Inclusive? Conceptions of Nationhood and AntiMuslim Attitudes in Europe." European Journal of Political Research 59 (2019): 114-36. https://doi.org/10.1111/1475-6765.12337.

Supriyadi. "Community Of Practitioners : Solusi Alternatif Berbagi Pengetahuan Antar Pustakawan." Lentera Pustaka Jurnal Ilmu Perpustakaan Informasi Dan Kearsipan 2, no. 2 (2017): 83-93. https://doi.org/10.14710/lenpust.v2i2.13476.

Susanto, Ali, and Muh. Farozin. "PENGARUH KONFORMITAS, KETERAMPILAN SOSIAL DAN PERSEPSI TERHADAP SINETRON ANAK JALANAN TERHADAP PERILAKU AGRESIF." Harmoni Sosial: Jurnal Pendidikan IPS 5, no. 1 (2018): 93-104. https://journal.uny.ac.id/index. php/hsjpi/article/view/15001/11415.

Sutrisno, Edy. “Aktualisasi Moderasi Beragamadi Lembaga Pendidikan.” Jurnal Bimas Islam 12, no. 2 (2019): 323-48. https://doi.org/10.37302/jbi.v12i2.113. 
Tomass, Mark. The Significance of Religious Identity. The Religious Roots of the Syrian Conflict. New York: Palgrave Macmillan, 2016. https://doi. org/10.1057/9781137525710_2.

Yustiani. "Nasionalisme melalui Pendidikan di Sekolah Pada Siswa SMA di Wilayah Perbatasan Kalimantan Barat." Jurnal SMaRT Studi Masyarakat, Religi Dan Tradisi 4, no. 1 (2018): 111-23. https://doi.org/10.18784/smart.v4i1.578.g324. 